of American Societies for Experimental Biology. The material is presented in the form of tables, graphs, diagrams, nomograms and line charts. Three hundred and eighty investigators have taken part in the compilation and much trouble has been taken to obtain accuracy, to eliminate misprints and to exclude material of questionable validity. Apart from blood, fields covered include urine, lymph, hæmolymph, cerebrospinal fluid, body water, various secretions of the digestive tract, reproductive secretions, milk, sweat, sebum and the fluids of the ear and eye. Among the species, man occupies the first place, but the information extends to numerous other vertebrate and invertebrate organisms.

While the data of physical and chemical reference books are usually constants which have been measured with a known accuracy, biological data are, as a rule, not so definable: they are not constants and their scatter is in many cases not sufficiently known. The figures given in the book are therefore bound to be of varying degrees of reliability, but this difficulty has been effectively met by detailed references to the sources of information. In fact the references given may well prove to be one of the most valuable features of a very useful mine of factual information.

H. A. KREBS

\section{A NEW STANDARD WORK ON COCOA}

Cocoa

By D. H. Urquhart. Second edition. (Tropical Agriculture Series.) Pp. $\mathrm{xxv}+293+129$ plates. (London: Longmans, Green and Co., Ltd., 1961.) 40s. net.

THIS book was originally published in 1955 and two additional impressions were issued in 1955 and 1956. The new (second) edition attempts to bring the subject-matter up to date. It contains one entirely new chapter (on manuring) and several of the chapters of the first edition have been combined in the second. The total number of pages has thus been increased from 230 to 293 . The book is one of a series on tropical agriculture of which five volumes have already been published. The author of Cocoa was formerly director of agriculture of Ghana, West Africa, and adviser in cocoa-growing to Messres. Cadbury Bros., Ltd., Bournville, Birmingham, England.

The book includes all the detailed information needed by practical cocoa farmers, as well as students and agricultural extension workers. Its usefulness is greatly enhanced by the excellent illustrations and the tables of data. Much progress has been made in the cocoa industry since the first edition of this book appeared in 1955, particularly in the control of pests and diseases of the cocoa tree, and the detailed specification of the atmospheric and soil environment necessary for maximum production of cocoa. Thus, in the chapters concerning soils and manuring, the results of researches carried out in recent years in Ghana by the late C. F. Charter and in Belgian Congo by M. V. Homes have been incorporated into the new edition. The establishment, maintenance and costings of the cocos plantation, the rehabilitation of the derelict and unremunerative plantation, and the preparation and grading of the crop for market, receive detailed consideration in no less than seven chapters and nine appendixes, spanning a total of 159 pages or 50 per cent of the total number of pages comprising the book, thus stress- ing the essentially practical outlook. That Urquhart's book is providing a much-needed standard work on cocoa and one which is a worthy successor to the classical works on the subject written by C. J. J. Van Hall and by J. H. Hart, which have long been out of print, is indicated by the fact that the first edition and its two impressions were exhausted after only five years had elapsed. The need for a Spanish version has already become manifest, and the task of translation has been undertaken by the Inter. American Institute of Agricultural Sciences at Turrialba, Costa Rica. Publication of the Spanish edition is expected shortly; it should add to the increasing demand for the book by making it available to cocoa growers in tropical America.

\section{LONDON LIBRARIES}

The Libraries of London

Edited by Raymond Irwin and Ronald Staveley. Second, revised edition. Pp. 332. (London : The Library Association, 1961.) $36 s$.

7 HE first edition of this work, published in 1949 , was based on lectures delivered during a course at the School of Librarianship and Archives, Univer. sity College, London, and was intended to supplement but not replace R. A. Rye's Students Guide to the Libraries of London. That work has long been out of print and even the first edition of The Libraries of London is now largely out of date. Accordingly, the new edition attempts to present a much fuller picture of the library resources of London. All the chapters have been carefully revised and most have been largely re-written; there is a new chapter on the University College Library, and separate chapters on the University of London Library, on the British Library of Political and Economic Science, while the other university libraries are described in a separate chapter. Additional chapters deal with the music libraries, the ecclesiastical and theological libraries, the industrial libraries, technical and professional libraries and those of the learned societies, and of the London County Council, while that on the Public Record Office is omitted. Apart from the London Library, no attempt is made to describe the commercial and subscription libraries, and likewise there is no reference to the libraries associated with the offices of the great national newspapers.

The individual chapters are the work of different authors, all authorities in their field, but what is gained in authority is sometimes offset in part by lack of balance, and diversity of scale and treatment. That on the Science Museum Library, by the late H. T. Pledge, is frankly episodical, and besides its historical or descriptive lacunæ, it has scant reference to future developments. The Patent Office Library is more adequately covered, but there are some surprising omissions in the chapter on Government Departmental libraries, while that on industrial libraries is scarcely of greater value than as a reminder of the existence of such libraries ; it is content to list and describe those of the British Aluminium Com. pany, the Cement and Concrete Association, and the British Paper and Board Industry Research Association. Nevertheless, used with imagination, this book, produced in accordance with the high standards which are customary with the Library Association, forms a most useful and convenient guide to the bibliographical resources of London.

\section{R. Brightman}

